\title{
Historical trends of food self-sufficiency in Africa
}

\author{
Yibo Luan · Xuefeng Cui • Marion Ferrat
}

Received: 24 June 2012 / Accepted: 1 April 2013 /Published online: 7 May 2013

(C) The Author(s) 2013. This article is published with open access at Springerlink.com

\begin{abstract}
The majority of African countries are stricken by food shortages and undernourishment, with much of the population lacking reliable access to food supplies and basic dietary requirements. In this paper, we analyze past trends of food production and consumption in Africa, both for the continent as a whole and for 52 individual countries within it. Fluctuations in the self-sufficiency ratio (SSR) are used to characterize the stability of a country's capacity to sustain its own population, and GDP per capita is taken as representative of national purchasing power. Our study shows that Africa's food self-sufficiency is lower today than it was throughout the entire study period. This is probably a result of demographic expansion, leading to a greater increase in food demand than in food production. At the national level, a decrease in SSR mainly occurred in Northern and Southern Africa, and high SSR fluctuations (i.e. low stability) always appeared in conjunction with low SSR levels. Although "low SSR-low GDP" countries face the most serious food insecurity conditions, both "low SSR-high GDP" and "high SSR-low GDP" countries also need attention.
\end{abstract}

Keywords Africa Self-sufficiency ratio $\cdot$ Fluctuation · GDP per capita

\section{Introduction}

According to the Food and Agriculture Organization (FAO) of the United Nations (FAO 2003), food security is a

\section{Y. Luan $\cdot$ X. Cui $(\bowtie) \cdot$ M. Ferrat}

State Key Laboratory of Earth Surface Processes and Resource Ecology, College of Global Change and Earth System Science, Beijing Normal University, Beijing, People's Republic of China e-mail: xuefeng.cui@bnu.edu.cn

\section{Y. Luan}

e-mail: whuyimu@gmail.com

M. Ferrat

e-mail: marion.ferrat@gmail.com situation that exists when all people, at all times, have physical, social, and economic access to sufficient, safe, and nutritious food that meets their dietary needs and food preferences for an active and healthy life. In 2010, an estimated 925 million people were affected by undernourishment globally (FAO 2011), an increase from the 848 million estimated in 2007. Despite a marked growth in global food production in the past half-century, more than one in seven people today still do not have access to basic dietary requirements and sufficient protein and energy input (Godfray et al. 2010). South Asia and Sub-Saharan Africa are the regions most affected by unreliable food access and undernourishment (Spielman et al. 2010), with $30 \%$ of world hunger concentrated in the latter region alone (FAO 2011). Given the extent of undernourishment in Africa, a quantitative and detailed assessment of the present production-consumption balance situation and its historical trends is necessary to understand the main issues underlying the African food security crisis.

Quantifying and assessing food security is complex and calls for the understanding of different social, economic, and biological factors such as food production rates, environmental conditions and the socio-political situation of different regions (Godfray et al. 2010; Acevedo 2011). One of the basic issues when dealing with food security is the food self-sufficiency of a certain region or country. Self-sufficiency is the ability of a region to sustain its own requirement for food and is therefore dependent on two factors: production and consumption (FAO 2001). The sensitivity of food security in Africa is associated with environmental variables, such as climate change, (Muller et al. 2011), poverty and lack of access to food (Scanlan 2001; Sadler and Magnan 2011), demographic and economic factors (such as population growth and urbanization, Gaiser et al. 2011) and political failures in adjustment and market liberalization reforms (Shiferaw et al. 2011). All these factors directly influence the availability or production 
of food and therefore self-sufficiency and food security (Brown 2005; Foley et al. 2005). Gaiser et al. (2011) suggest that such factors may influence the potential of certain regions to increase their food import and potentially reduce food self-sufficiency, while others are likely to remain trapped in poverty. The consumption aspect is also important, for example the interactions between population growth, urbanization, economic growth, dietary pattern changes, and demand for food (Gerbens-Leenes and Nonhebel 2005; Wirsenius et al. 2010).

Despite great advances in the understanding of food security and its underlying factors, most previous studies have focused on qualitatively assessing two aspects of food security, namely, production and consumption, and on determining the underlying reasons for the high food insecurity faced by Africa today. Very few studies have considered the historical trends of the balance between food production and demand (Amalu 2002; Devereux 2009; de Graaff et al. 2011) and its effect on historical trends in self-sufficiency. However, a better understanding of such historical trends is necessary to characterize more effectively the development of a region's ability to be self-sufficient and the potential problems it may face. Considering the heterogeneity of African nations in terms of food producing systems and their socio-political drivers, it is important and sensible to assess the balance between food production and consumption on a national basis. The aim of this paper is to analyze the past trends in the African food production-consumption balance by studying the changes in the self-sufficiency ratio (SSR) from 1961 to 2007, to provide an overview of the extent to which individual African countries can meet their own food demands and to characterize the sources of potential problems. The SSR is defined as follows (FAO 2001):

$\mathrm{SSR}=\frac{\text { production }}{\text { production }+ \text { imports }- \text { exports }}$

First, we assess the trends in African SSR on a continental scale and subsequently investigate its trends on a national basis. We then provide a deeper understanding of the fluctuations of SSRs and their relations to the economic situation in each country in order to clarify where potential problems may lie in the future.

\section{Materials and methods}

Data

Our analysis covers the period from 1961 to 2007. The statistical data related to production and consumption used in this study, including staple cereals and starchy roots, were taken from the FAOSTAT Food Balance Sheet (FAOSTAT
2010). Population data were obtained from the World Bank. Equatorial Guinea, Mayotte and Saint Helena were excluded from the statistical analyses because data from these states were not available. Given the division of the People's Democratic Republic of Ethiopia (PDR) into Eritrea and Ethiopia in 1992, we assume that the data for Ethiopia prior to 1993 were the same as those for Ethiopia PDR and we do not consider Eritrea here. However, GDP data for certain states were not available throughout the entire period. The statistical analysis for GDP per capita covers the period from 1998 to 2007.

\section{Study area}

Africa is the world's second-largest and second most populous continent, with an area of approximately 30.2 million $\mathrm{km}^{2}$ (11.7 million square miles), including adjacent islands, and a population of just over 1.0 billion people, making up approximately $14.14 \%$ of the world's population. However, chronic poverty and food insecurity trouble the continent. Africa is facing "an urgent and imminent threat to its peace, security, and stability" (Clover 2003), with Sub-Saharan Africa being particularly affected. In 2010-12, 234 million people $(23.4 \%)$ faced undernourishment in Africa, the second highest proportion in the world after Southern Asia (304 million out of the total 868 million: $35.0 \%$ ) (FAO 2012). Moreover, about 327 million (45 \%) of sub-Saharan Africa's 726 million people live below the international poverty line of US $\$ 1$ a day, a figure that is on the rise (Watkins 2009).

A farming system has a broadly consistent resource base, enterprise patterns, household livelihoods and constraints, which directly and indirectly influence the SSR of the region in which it occurs (Dixon et al. 2001a). In Africa, there are over 16 kinds of farming systems, among which five are particularly important for their potential to increase growth and reduce poverty: Tree cropping, Maize mixed farming, Agro-pastoral millet/sorghum farming, Cereal-root crop mixed farming and Irrigated farming (Dixon et al. 2001a). Starchy roots and cereals are the two dominant types of staple food (FAOSTAT 2010). A detailed description of population, GDP, production, consumption, and land resource for each African country is given in the Appendix (Table 2).

Methods

\section{Main indices}

The definition of food security proposed by the FAO is divided into four categories: (1) food availability, (2) food access, (3) utilization, and (4) stability (IFRC 2006). In this work, we focus on food availability as 
measured by the SSR defined by the FAO (2001: see above), which gives the ratio of production to domestic use. Production is the total production of cereals (excluding beers) and starchy roots. Domestic use is calculated using the food supply data from the food balance sheet (FAOSTAT 2010). Food supply for domestic use is regarded as food consumption, which may include all waste during transportation and post-harvest processing. It is defined as follows:

$$
\begin{aligned}
\text { production } & + \text { imports }- \text { exports } \\
& + \text { changes in stocks (decrease or increase }) \\
& =\text { food consumption }
\end{aligned}
$$

In the context of food security, the SSR usually indicates the extent to which a country relies on its own production resources. Therefore, the higher the ratio, the greater the ability of a country to sustain its own population. Conversely, a lower SSR indicates a higher dependence on food resources from outside the environment (Wang 2009). Although the SSR can be an appropriate metric for assessing the supply situation for individual commodities, a degree of caution should be observed when considering the overall food situation (FAO 2001). Here, we assume that the production of the two kinds of staple foods (cereals and starchy roots) in each country is first used to supply the country's own population before being exported. The stability of SSR in each country is then characterized by its fluctuation coefficient (please refer to the Appendix for details on statistical treatment). It is worth noting that the fluctuation coefficient of a given index can only measure the flux of the time series data rather than indicate the absolute trend of the data.

The GDP per capita can measure the ability of a country to purchase food from import to meet the national demand and is therefore considered in this study. By measuring the relationship between SSR and GDP per capita, it is possible to examine how economic development and SSR changes in the future can influence food security.

The area of staple food harvested per capita was taken as the index of natural resources for each country. The average area harvested per capita from 1998 to 2007 was calculated, and a threshold of 0.1 ha/cap was assigned to distinguish between individual countries with low and high levels.

\section{Cereal equivalents (CE)}

According to the food balance sheet from FAO, the inhabitants of more than 20 countries in Africa consume cereals or starchy roots respectively as their staple food (based on the quantity of consumption). In order to unify the quantity of cereals and starchy roots, we transformed all the production and consumption data of the two staple foods into per capita cereal equivalents (CEs) (Rask and Rask 2011). The CE coefficients used here for this transformation were derived from the work of Rask and Rask (2011), in which 0.26 t of cereals are equivalent to $1 \mathrm{t}$ of starchy roots.

\section{HP filter}

A Hodrick-Prescott filter (HP filter) (Hodrick and Prescott 1997) was applied to the time series when examining developing trends. The HP filter is a mathematical tool separating the cyclical component of a time series from raw data to obtain a smoothed curve representation of a time series, one that is more sensitive to long-term than to short-term fluctuations. The filter was used to obtain the SSR trend of Africa and its production and consumption trends.

\section{Results and discussion}

Africa's production-consumption balance

As a whole, Africa's self-sufficiency declined from almost 1.0 in 1961 to 0.8 by 2007 (Fig. 1a), indicating the deterioration of Africa's capacity to meet its own population's demand for food in the past half-century. This trend can be divided into two phases, with a precipitous decline observed before 1986 and a flatter one thereafter (Fig. 1a). While consumption per capita increased during the study period, the production per capita decreased up to 1984 and then caught up with the 1961 value by 2007. Because of the expanding population, the gap between production and consumption widened over the study period (Fig. 1b). Compared with average world production and consumption per capita, those of Africa remained at a very low level (Fig. 1b). The steadily growing population and its continuing growth aggravated the imbalance between production and consumption, reducing the SSR (Fig. 1a) and implying an increased reliance on external supplies (Fig. 1c). Food aid from the outside world made some contributions, mainly in the period 1975 to 1990 but food from net import has played a major role in narrowing the gap between production and consumption throughout the study period and has become more pronounced in recent years.

Table 1 presents the fluctuation coefficient of Africa's SSR for the entire period studied and for the sub-periods 1961 to 1985 and 1986 to 2007. The fluctuation coefficient 
Fig. 1 Trends of cereal equivalent (CE) productionconsumption balance in Africa and the world and proportion of food consumption contributed by net import and aid 19612007. a Trend of selfsufficiency ratio (SSR) in Africa. The black line denotes the original data; the gray line denotes the trend of SSR processed by the HodrickPrescott HP filter (see text for explanation). The straight lines illustrate the precipitous decline of SSR between 1961 and 1985 and the less steep decline from 1986 to 2007. b Trends of production and consumption per capita in Africa and the world. All data were processed by the HP filter. The smooth red line denotes the trend of world production per capita and the dotted red line denotes that for Africa. The smooth blue line denotes the trend of world consumption per capita and the dotted blue line that for Africa. The gray bars denote the population of Africa. c Food net import and food aid as proportions of total consumption in Africa a

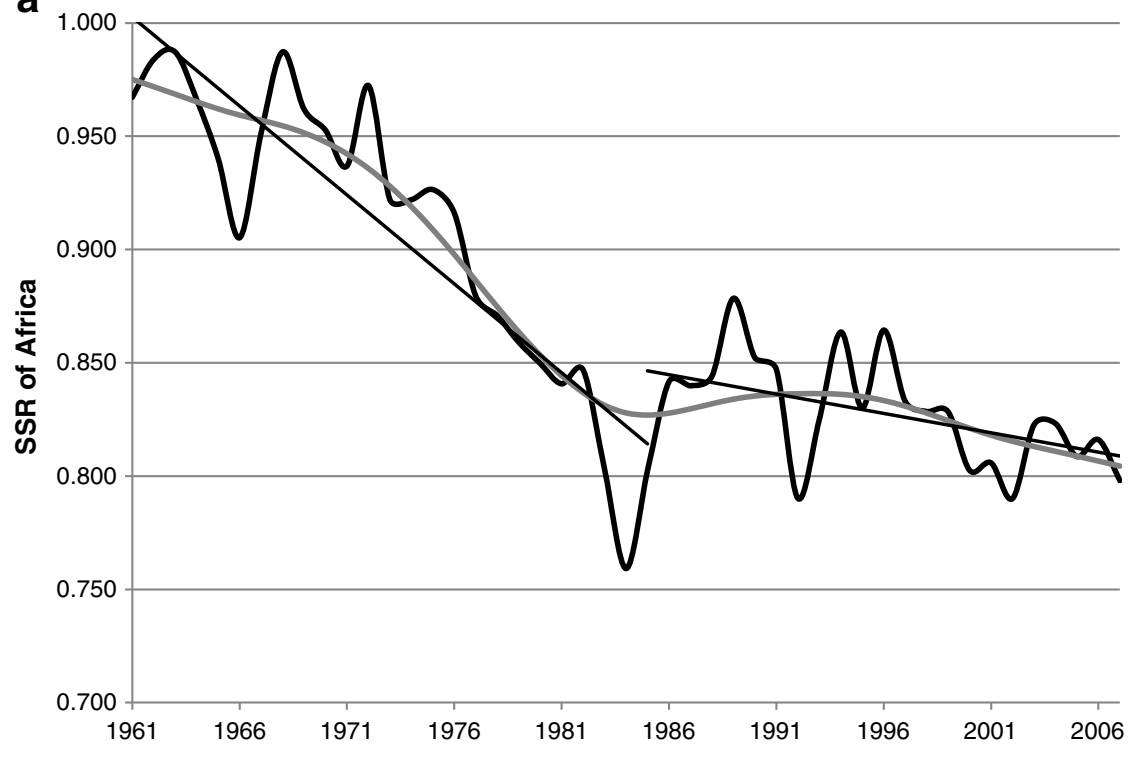

b

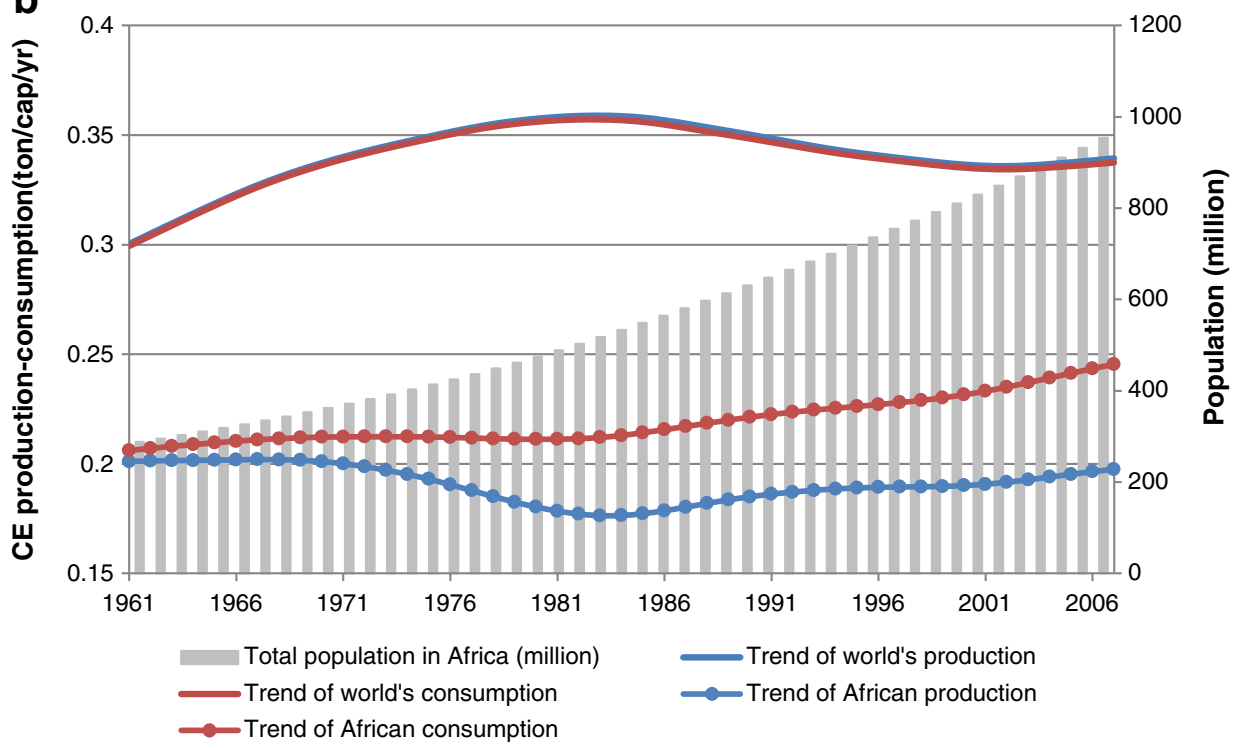

C

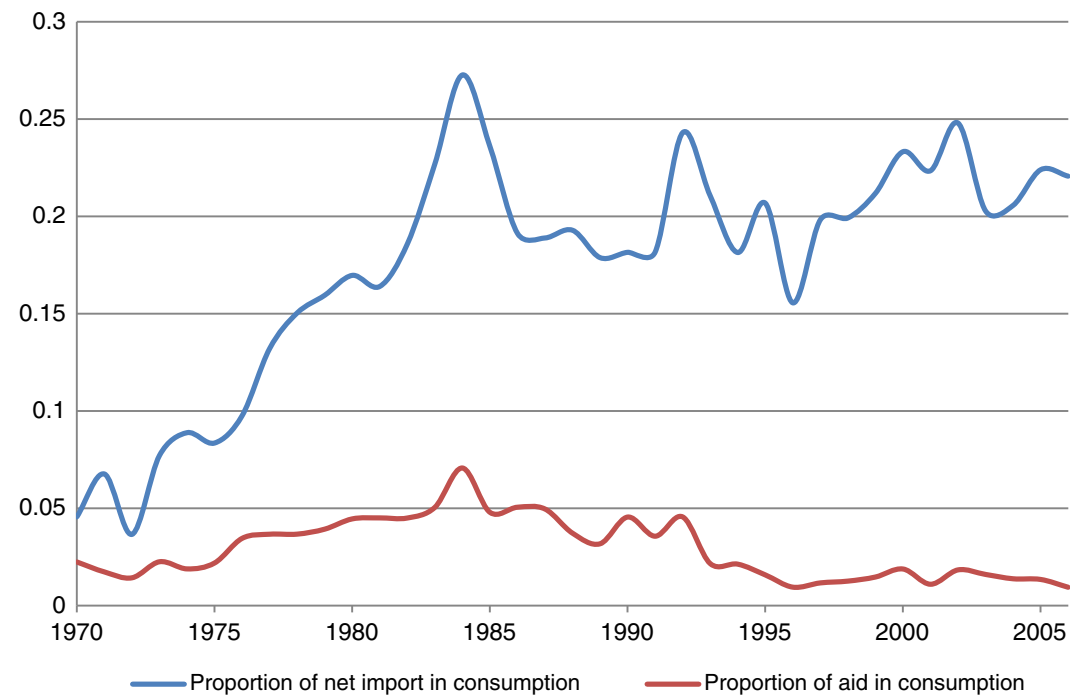


Table 1 Fluctuation of self-sufficiency ratio (SSR), production and consumption per capita in Africa

\begin{tabular}{lllll}
\hline & Period & Average & $\begin{array}{c}\text { Standard } \\
\text { deviation }\end{array}$ & $\begin{array}{c}\text { Fluctuation } \\
\text { coefficient }\end{array}$ \\
\hline SSR & $1961-1985$ & 0.908 & 0.064 & 0.071 \\
& $1986-2007$ & 0.829 & 0.024 & 0.029 \\
& $1961-2007$ & 0.871 & 0.064 & 0.073 \\
Production & $1961-1985$ & 0.192 & 0.016 & 0.084 \\
per capita & $1986-2007$ & 0.190 & 0.009 & 0.050 \\
& $1961-2007$ & 0.191 & 0.013 & 0.069 \\
Consumption & $1961-1985$ & 0.211 & 0.009 & 0.045 \\
per capita & $1986-2007$ & 0.229 & 0.011 & 0.049 \\
& $1961-2007$ & 0.219 & 0.014 & 0.063 \\
\hline
\end{tabular}

over the study period was 0.073 , with the first half displaying more instability than the second half. The volatility of the SSR indicates the unstable nature of Africa's food production-consumption system through time, notably during the first sub-period (Wang 2006). Nonetheless, despite an overall decrease in Africa's SSR in the past 50 years, the food situation seems to have stabilized. Considering the two factors influencing SSR individually, both production per capita and consumption per capita display similar levels of instability over the entire period, although the first 25 years were characterized by unstable food production.

Given the continuing decrease in SSR in recent years, this trend is likely to continue in the near future (Fig. 1a). The deterioration of the production-consumption balance in Africa is the result of the complex interaction between a multitude of factors, which differ from country to country and deserve further intensive studies (Clover 2003; Devereux 2009; de Graaff et al. 2011; Muller et al. 2011).

Production-consumption balance in each country

\section{SSR}

The SSR decreased in many countries between 1961 and 2007 according to the data available (Fig. 2). Comparing the SSR in 1961, 1985 and 2007, decreasing trends occurred mainly in Northern and Southern Africa (for example, the SSR in South Africa was higher than 1.0 in 1961 and decreased to less than 0.8 in 2007). In 1961, nine countries (Western and Central Africa: Mali, Niger, Chad; Eastern Africa: Rwanda; Southern Africa: Angola, Malawi, Zimbabwe, South Africa and Madagascar) had SSR ratios greater than 1 (Pedersen and Benjaminsen 2008) but, by 2007, only Malawi retained a ratio above 1 . Despite the presence of relatively affluent natural resources (Dixon et al. 2001b), Southern Africa (i.e., Botswana, South Africa, and Angola,
Fig. 2) faces a relatively heavy pressure on food security, as indicated by the continuing decline in SSR. This situation is caused by such factors as fluctuating food prices, chronic poverty, effects of climate change - notably extreme weather events-poor government and HIV/AIDS. High food price is a double blow: farmers lose income from harvest failure, causing them to leave the land and the poor are unable to afford enough food (Van Zyl and Coetzee 1990; de Graaff et al. 2011). Chronic poverty causes people in Southern Africa to have no assets, skills, or opportunities to escape poverty; thus, they have no knowledge as to how to improve their farming status. People who are unable to work because of age, disability or young children are more susceptible to illness, when facing food shortage (Maunder and Wiggins 2007). As Tschirley and Jayne (2010) indicate, government action during food crises in Southern Africa frequently exacerbates the problems; the lack of trust between public and private sectors contributes to the inability to make credible commitments. Failing governance and policymaking, for example the political impasse in Zimbabwe, the decline of the economy, and the loss of government capacity to maintain health and social welfare programs, cause the population of all countries to face long-term food insecurity and malnutrition (Maunder and Wiggins 2007). Climate variation and change are two of the several additional interacting factors affecting food security. Studies have shown their negative effects on farming systems in Africa, with Southern Africa being particularly vulnerable to these effects (Bohle et al. 1994; Gregory et al. 2005; Giorgi 2006; Eriksen et al. 2008). Specifically, the high incidence of HIV/AIDS in Southern Africa directly and indirectly affects labor markets (Maunder and Wiggins 2007; Drimie and Casale 2009). In Mali, Niger and Chad, located in the Sahel region, low rainfall and low water levels, poor harvests and lack of pasture have led to high food prices and serious food crises owing to their effects on agricultural production systems. Lack of water is a major limiting factor, as demonstrated by the Sahel drought of 1972 to 1974 . Despite this decreasing trend in the region, Egypt and Sudan showed an increase in SSR from 1985 to 2007 (Fig. 2).

In 2007 , the lowest SSR (i.e., 0.0 to 0.3 ) was predominantly observed in the northern part of Africa and in the island nations (aside from Madagascar). Indeed, the SSR of some northern countries decreased from above 0.5 to below 0.3 in the past half-century. Island countries had near-zero SSR values in 2007 owing to their limited natural resources. Northern Africa mainly has an arid farming system with a low level of agricultural productivity (Dixon et al. 2001a). The study by Sadler and Magnan (2011) showed that the Northern African region is the largest grain importing region in the world, with severe constraints on arable land and water coupled with a growing population and increasing incomes (Table 2 in Appendix). However, as nomadic 


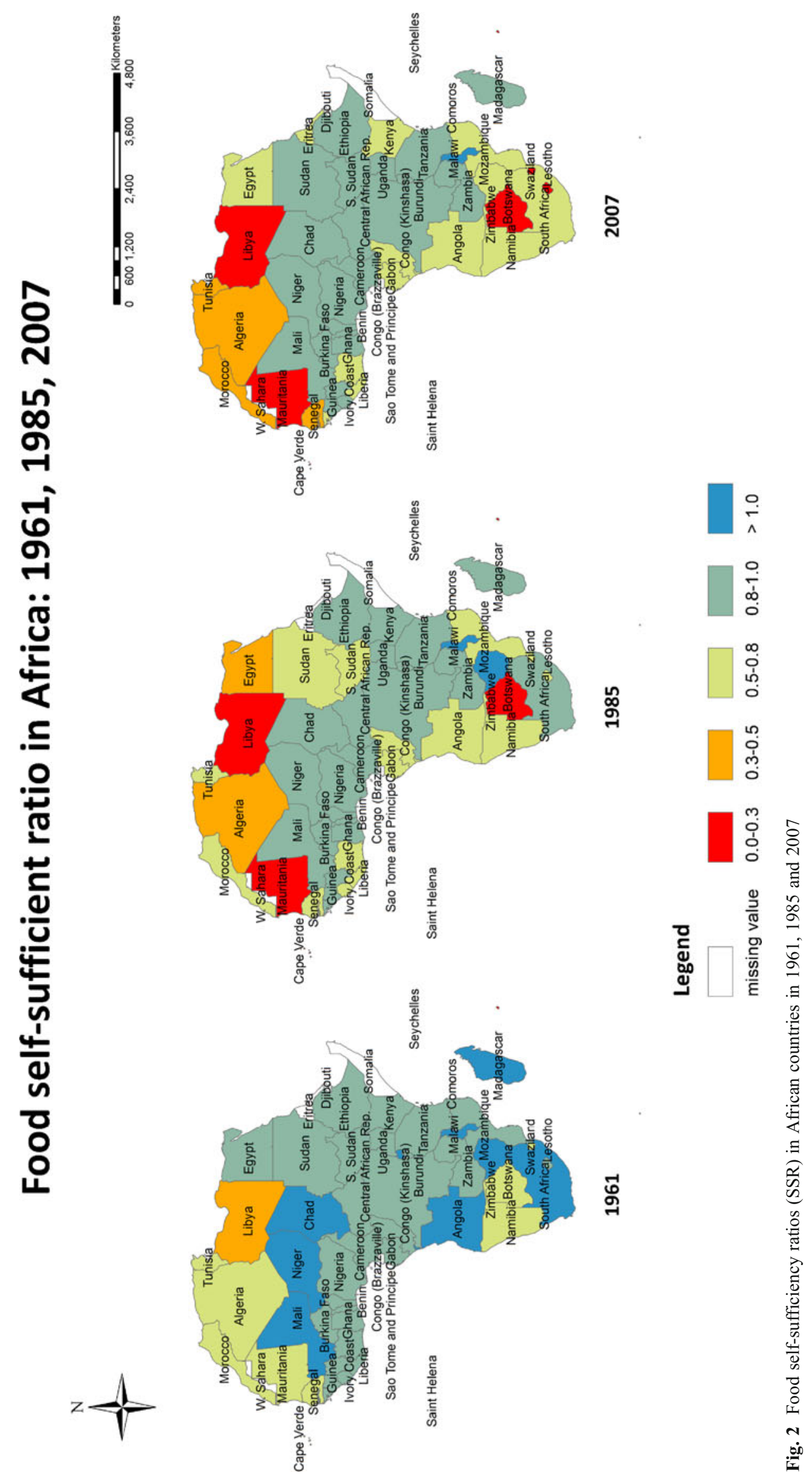


lifestyles are common in Northern Africa, nutrition from stocks and pastoral diet patterns, which are disregarded here, should also be considered (Pedersen and Benjaminsen 2008).

The rural semi-arid regions of North Western Africa (i.e., Senegal, Mauritania, Morocco, Algeria, and Tunisia) also suffered from low SSR during the study period (Fig. 2), with unstable and uncertain food security conditions affected by repetitive and severe phenomena such as extreme climatic events (Janin 2010). Based on estimates, 18 million people are still at risk in West and parts of Central Africa, mainly in the Sahel region (Oxfam 2012). Underdevelopment, low rainfall, forced migration, climate change, poverty, rising food prices and declining food stock are key factors contributing to Western Africa's food crisis. By contrast, countries in parts of Central Africa and Eastern Africa exhibited the most stable conditions between 1961 and 2007, with the SSR values consistently falling between 0.8 and 1.0. Detailed information regarding each country can be found in the Appendix (Table 2).

\section{SSR and its fluctuation}

The relationship between Africa's average SSR and its fluctuation coefficient from 1961 to 2007 across 52 African countries is shown in Fig. 3a and b. As illustrated in Fig. 3b, the higher the average SSR, the lower the fluctuation coefficient. In other words, countries with a greater ability to feed their people also have a greater ability to keep the production-consumption balance stable in the face of internal or external pressures.

However, this positive correlation between low fluctuation and high average SSR cannot be applied to all countries (Fig. 3a). For island countries, such as Cape Verde, Seychelles and Mauritius, limited land area is the major constraining factor of their food supply systems. Moreover, these island countries are characterized as having low average SSR and remarkably high fluctuation. Sao Tome and Principe, a tropical island country, is an exception which adopts agricultural cooperation and agriculture investment (Kyle 1999; Ahotondji 2011), has a relatively higher average SSR and lower fluctuation (i.e., 0.37 and 0.23 , respectively) than other island countries and even continental countries (e.g., Djibouti, which has intense fluctuation of 0.414315 and very low average SSR at 0.000128). Facing several internal and external constraints and impact factors, food production and supply systems in countries of Southern Africa are more sensitive to pressures. In particular, the SSR stability in Zimbabwe and South Africa is relatively unstable but both countries have a high average SSR (exceeding 1.0).

\section{SSR and GDP per capita}

As mentioned previously, the GDP per capita can be taken as a measure of the ability of a country to purchase food from imports to meet national demands. This measure is particularly useful for countries with a pronounced low SSR. As GDP data are only available from 1998 for all African countries, the relationship between average GDP per capita and SSR is only investigated in the last 10 years.

The average GDP per capita shows a negative relation with average SSR $\left(R^{2}=0.4668\right.$, Fig. 4$)$, indicating that the countries with the inability to meet their food consumption from their own resources generally have higher economic ability, enabling them to purchase food from outside their own borders. For example, Libya, whose economy depends primarily on revenues from the oil sector, has enough money to pursue projects such as agriculture development and the Great Manmade River in the Sahara desert. If countries are classified by the average area harvested per capita, those exhibiting the lowest harvested areas also show more negative correlations with SSR than the high-level countries $\left(R^{2}=0.39\right.$ and $R^{2}=0.33$, respectively). However, the dependence of these countries (classified as "low SSR-high GDP") on outside resources make them more sensitive and vulnerable to world economic and trade market fluctuations, notably those involving climate change (Schmidhuber and Tubiello 2007). In Libya, for example, poor people are much more vulnerable to food price as they cannot afford the higher price of imported food (World Food Programme 2011). Fluctuations of the trade market and higher food prices greatly affect the poor and increase hunger (Ghanem 2008; Ivanic and Martin 2008). Considering that those countries with low SSR are mainly limited by natural resources, future demographic and human pressures, such as population increase and the improvement of the poor's living standards by changing the dietary patterns, are likely to further affect the imbalance between low production and high consumption, causing the food security of these countries to become even more fragile.

In this paper, we classified countries into four categories (Fig. 4). Food security in countries having a high SSR but low GDP ("high SSR-low GDP”, Fig. 4a), which rely on agriculture to sustain their population's demand for food, is highly sensitive to factors such as climate change (Lobell et al. 2008; Schlenker and Lobell 2010; Muller et al. 2011) and degradation (Ramankutty et al. 2002; Smith et al. 2010; du Preez et al. 2011a, b). Negative changes in these factors can influence the natural aspects of farming systems, thus directly affecting food productivity. Given the lower economic potential of these countries, a key for maintaining self-sufficiency in the future is improving their ability to face and respond to future environmental changes.

The "low SSR-low GDP" countries (Fig. 4b, e.g., Mauritania and Lesotho) have neither the ability to meet their own consumption demands through domestic production nor the economic ability to import food and therefore face the 
Fig. 3 Average and fluctuation of self-sufficiency ratios (SSR) in Africa: 1961-2007. a

Distribution of the average of SSR and the fluctuation of SSR across Africa; b Relationship between the average SSR and its fluctuation: 1961-2007

a

Average and Fluctuation of SSR in Africa: 1961-2007
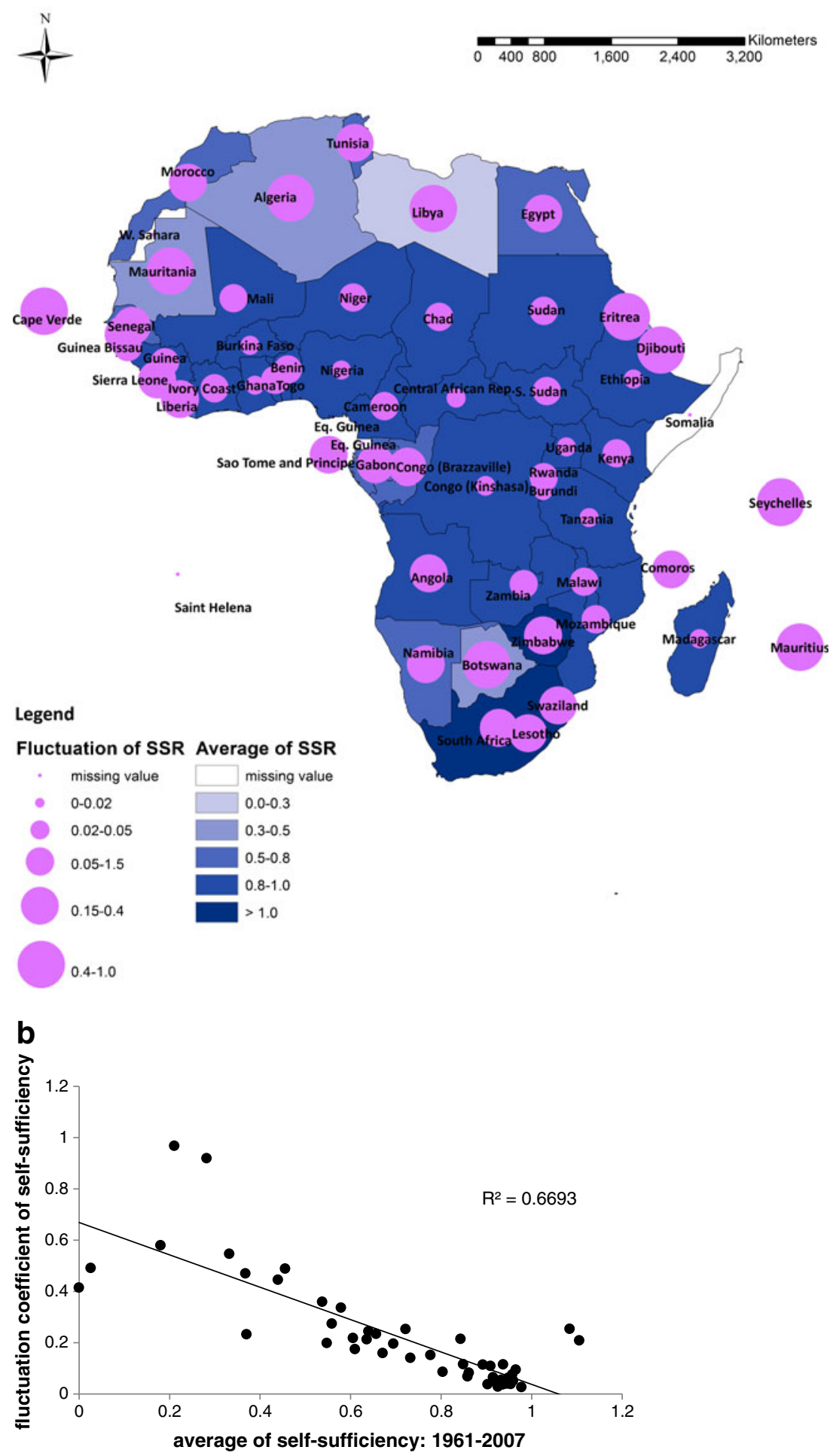

highest level of food insecurity. In contrast, those countries having a high SSR and GDP (i.e. South Africa, Fig. 4c) have the most secure and stable situation, although the highest SSR of 0.8 (Fig. 2) indicates that these countries still face a certain deficit in their production-consumption balance. The fourth category, "low SSR-high GDP" (Fig. 4d) has the economic ability to import food.

As shown by its Gini coefficient (a measure of statistical dispersion) (Fig. 5), Africa suffers from a seriously unbalanced domestic economy with wide disparities between the 


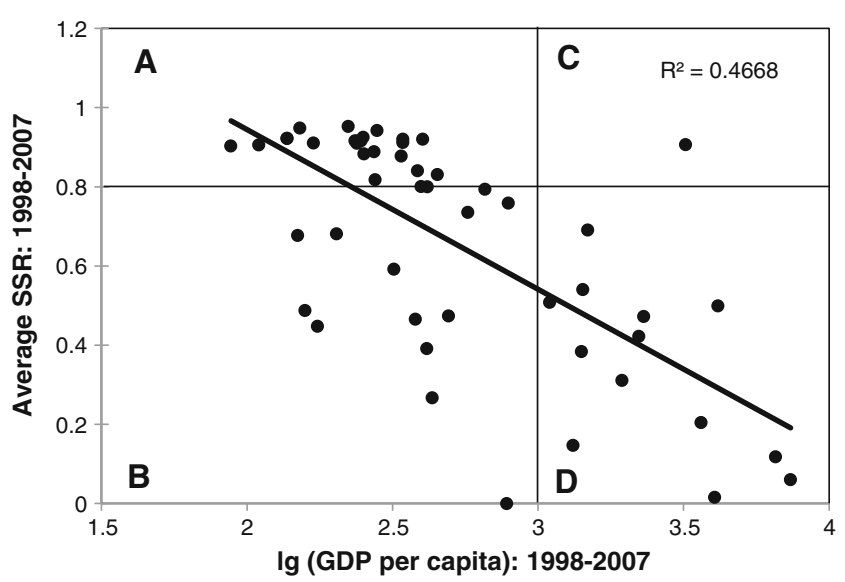

Fig. 4 Average GDP per capita and self-sufficiency ratios (SSR) in Africa: 1998-2007. The threshold between high and low SSR is 0.8 and that of the GDP per capita is 3 (log scale). Although the former threshold is below 1.0, it is relatively high for Africa. A GDP per capita below 3.0 represents an actual GDP per capita below 1000 US\$ a year at US\$ constant for the year 2000. Quadrant A indicates "high SSRlow GDP"; Quadrant B "low SSR-low GDP"; Quadrant C "high SSRhigh GDP"; Quadrant D "low SSR-high GDP"

rich and the poor. It seems that more needs to be done to increase the SSR and improve African countries' food security than just improving productivity even in those countries which have a relatively high economic or high natural resource level.

\section{Conclusion}

Past trends in African food production and consumption were analyzed to assess the past and present status of food security in Africa and provide insights into its possible causes. The SSR of Africa as a whole has decreased from 1.0 to 0.8 in the past five decades and was volatile throughout this time although recently it has become more stable. This decrease in

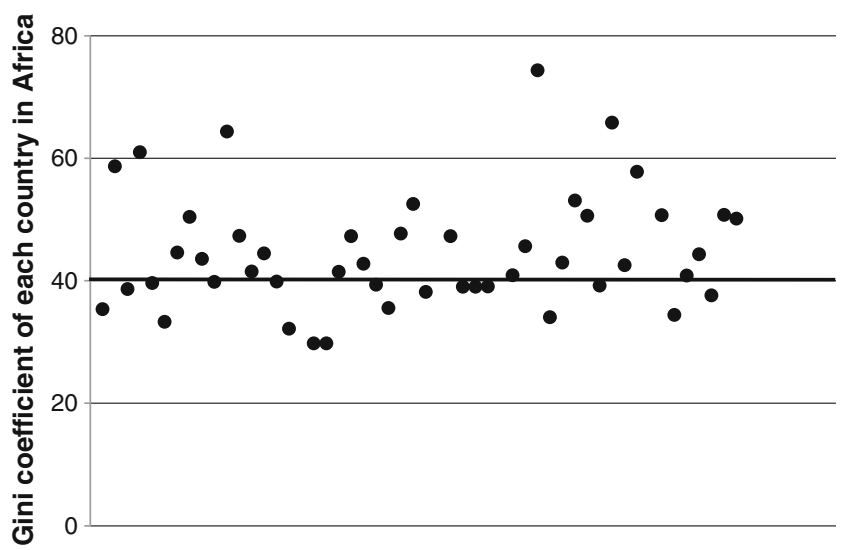

Fig. 5 Gini coefficients of African countries. Data from each country (although not all from the same year) are represented by single points on the plot. Source: World Bank sustainability ratio can be explained by the increasingly large gap between the growth rates of food production and consumption. Net imports of food have been the main solution to narrowing the gap in SSR in recent years.

On a national scale, differences can be observed throughout the African continent. Northern and Southern African countries have suffered the most severe decreases in SSR because of different factors. The northern countries seem to be mainly influenced by their scarce natural resources, along with climate change, and the decreasing self-sufficiency of the southern countries is caused by multiple stress factors. Most central African nations and some western countries are characterized by a more stable SSR of between 0.8 and 1.0. An apparent phenomenon is that, in Africa, a country with a higher ability to keep the production-consumption balance stable in the face of inside and outside pressures is also characterized by a high SSR. However, South Africa and Zimbabwe show high SSR fluctuations despite having a relatively high average SSR.

Considering the relationship between the current decadal average GDP per capita and the SSR, countries with a comparatively low SSR generally have high GDP per capita. Therefore, "low SSR-high GDP" countries, such as Libya, have the ability to purchase food from outside but are more sensitive and vulnerable to world economic and trade market fluctuations. For "high SSRlow GDP" countries, the negative effect of climate change and degradation on farming systems can cause hardship because of their lower economic power to mitigate the gap between production and demand through imports. How to improve their adaptability to respond to future changes in their agricultural environment is a key point that should be addressed by these countries.

However, as indicated by recent studies, although food production has the largest effect on African selfsufficiency in all regions, the recent increased food supply should not be ignored. GDP per capita, which is the indicator of economic development, displays a close relationship with consumption (Gerbens-Leenes et al. 2010). As income increases, so does consumption and diets become more diverse, although the consumption level in Africa is greatly below that of the world average. Moreover, the increasing demand for food owing to the increasing population will put more pressure on food security in the future. The increasing consumption, owing to changes in diet and population, determines the arable land requirement (Gerbens-Leenes and Nonhebel 2005) while climate change has a crucial influence on arable land resources (Gregory et al. 2005; Muller et al. 2011) through its effects on soil, water, temperature and pests. The tension between productivity and increased demand is likely to put more pressure on food security in Africa in the future. 
Acknowledgments The authors are grateful for the generous comments from the editor and anonymous reviewers, which greatly improved the quality of the manuscript. This work was supported by the National Basic Research Development Program of China (Grant Nos. 2011CB952001 and 2010CB428502), National Science Foundation of China (Grant No. 41271542), and Program for New Century Excellent Talents in University (Grant No. NCET-09-0227), and the Fundamental Research Funds for the Central Universities and the Scientific

\section{Appendix}

Calculating the fluctuation coefficient

The stability of SSR characterizes the variability during the study period from 1961 to 2007, with lower data stability indicating a more unstable food security situation. To measure the stability, the fluctuation coefficient is calculated for SSR, as indicated by the coefficient of variation of the data. The fluctuation coefficient is calculated as the ratio of the
Research Foundation for the Returned Overseas Chinese Scholars, State Education Ministry.

Open Access This article is distributed under the terms of the Creative Commons Attribution License which permits any use, distribution, and reproduction in any medium, provided the original author(s) and the source are credited.

standard deviation to its mean value as shown in the following equation:

$\delta=\frac{\mathrm{s}}{\overline{\mathrm{y}}}=\frac{\sqrt{\frac{1}{\mathrm{n}} \sum_{\mathrm{i}=1}^{\mathrm{n}}\left(\mathrm{y}_{\mathrm{i}}-\overline{\mathrm{y}}\right)^{2}}}{\frac{1}{\mathrm{n}} \sum_{\mathrm{i}=1}^{\mathrm{n}} \mathrm{y}_{\mathrm{i}}} * 100 \%$

where $\delta$ is the fluctuation coefficient of each index during the statistical period, $\mathrm{s}$ is the standard deviation of indicator's values, $\bar{y}$ is the average value of indicator of all years, $y_{i}$ is the value of indicator in each year and $n$ is the number of years.

Detailed information about each country

Table 2 Overview of the 52 African countries considered in this paper: the 2007 self-sufficiency ratio (SSR), area harvested, GDP per capita, average inter-annual change of cereal equivalent (CE) production, average inter-annual change of CE consumption and rate of population growth

\begin{tabular}{|c|c|c|c|c|c|c|}
\hline Nation & $2007 \mathrm{SSR}$ & $\begin{array}{l}\text { Area } \\
\text { harvested } \\
(\text { ha/cap/yr) }\end{array}$ & $\begin{array}{l}\text { GDP per capita } \\
\text { (constant }^{2000 \text { US\$) }}{ }^{\mathrm{a}}\end{array}$ & $\begin{array}{l}\text { Average } \\
\text { inter-annual } \\
\text { change of CE } \\
\text { production }^{\mathrm{b}}\end{array}$ & $\begin{array}{l}\text { Average } \\
\text { inter-annual } \\
\text { change of CE } \\
\text { consumption }^{\text {b }}\end{array}$ & $\begin{array}{l}\text { Rate of } \\
\text { population } \\
\text { growth }^{\text {b }}\end{array}$ \\
\hline Algeria & 0.35 & 0.09 & 2158.57 & 0.15 & 0.05 & 0.02 \\
\hline Angola & 0.78 & 0.15 & 1237.68 & 0.01 & 0.02 & 0.03 \\
\hline Benin & 0.90 & 0.17 & 353.81 & 0.01 & 0.01 & 0.03 \\
\hline Botswana & 0.25 & 0.03 & 4237.27 & 0.15 & 0.02 & 0.03 \\
\hline Burkina Faso & 0.92 & 0.23 & 260.25 & 0.02 & 0.02 & 0.02 \\
\hline Burundi & 0.81 & 0.06 & 109.73 & -0.01 & 0.00 & 0.02 \\
\hline Cameroon & 0.80 & 0.10 & 692.00 & 0.00 & 0.00 & 0.03 \\
\hline Cape Verde & 0.06 & 0.06 & 1656.58 & 0.16 & 0.06 & 0.02 \\
\hline Central African Republic & 0.88 & 0.13 & 231.06 & -0.01 & -0.01 & 0.02 \\
\hline Chad & 0.93 & 0.25 & 285.24 & 0.02 & 0.02 & 0.03 \\
\hline Comoros & 0.43 & 0.04 & 374.83 & -0.01 & 0.01 & 0.03 \\
\hline Congo & 0.51 & 0.04 & 1156.47 & -0.01 & 0.00 & 0.03 \\
\hline Côte d'Ivoire & 0.72 & 0.09 & 530.13 & 0.00 & 0.00 & 0.04 \\
\hline Democratic Republic of the Congo & 0.88 & 0.06 & 93.56 & -0.02 & -0.01 & 0.03 \\
\hline Djibouti & 0.00 & 0.00 & 842.46 & 0.03 & 0.12 & 0.05 \\
\hline Egypt & 0.69 & 0.04 & 1697.08 & 0.01 & 0.02 & 0.02 \\
\hline Eritrea & 0.70 & 0.11 & 151.23 & 0.33 & 0.14 & 0.03 \\
\hline Ethiopia & 0.95 & 0.12 & 175.51 & 0.04 & 0.03 & 0.03 \\
\hline Ethiopia PDR & NA & NA & 175.51 & -0.02 & 0.01 & 0.03 \\
\hline Gabon & 0.50 & 0.07 & 4148.43 & 0.00 & 0.01 & 0.02 \\
\hline Gambia & 0.47 & 0.12 & 322.86 & 0.00 & 0.01 & 0.04 \\
\hline Ghana & 0.86 & 0.12 & 315.19 & 0.02 & 0.02 & 0.03 \\
\hline Guinea & 0.84 & 0.20 & 400.51 & 0.01 & 0.01 & 0.02 \\
\hline
\end{tabular}


Table 2 (continued)

\begin{tabular}{|c|c|c|c|c|c|c|}
\hline Nation & 2007 SSR & $\begin{array}{l}\text { Area } \\
\text { harvested } \\
(\text { ha/cap/yr) }\end{array}$ & $\begin{array}{l}\text { GDP per capita } \\
(\text { constant } \\
2000 \text { US\$) }\end{array}$ & $\begin{array}{l}\text { Average } \\
\text { inter-annual } \\
\text { change of CE } \\
\text { production }^{\mathrm{b}}\end{array}$ & $\begin{array}{l}\text { Average } \\
\text { inter-annual } \\
\text { change of CE } \\
\text { consumption }^{\text {b }}\end{array}$ & $\begin{array}{l}\text { Rate of } \\
\text { population } \\
\text { growth }^{\text {b }}\end{array}$ \\
\hline Guinea-Bissau & 0.78 & 0.10 & 144.17 & 0.01 & 0.01 & 0.02 \\
\hline Kenya & 0.78 & 0.06 & 457.23 & 0.00 & 0.00 & 0.03 \\
\hline Lesotho & 0.27 & 0.08 & 462.11 & 0.04 & 0.02 & 0.02 \\
\hline Liberia & 0.52 & 0.07 & 144.43 & 0.00 & 0.01 & 0.03 \\
\hline Libya & 0.11 & 0.06 & 7553.52 & 0.05 & 0.06 & 0.03 \\
\hline Madagascar & 0.90 & 0.11 & 260.24 & -0.01 & -0.01 & 0.03 \\
\hline Malawi & 1.06 & 0.12 & 161.34 & 0.05 & 0.03 & 0.03 \\
\hline Mali & 0.92 & 0.29 & 258.03 & 0.02 & 0.02 & 0.02 \\
\hline Mauritania & 0.29 & 0.08 & 472.40 & 0.02 & 0.03 & 0.03 \\
\hline Mauritius & 0.02 & 0.00 & 4649.92 & 0.05 & 0.01 & 0.01 \\
\hline Morocco & 0.32 & 0.16 & 1647.72 & 0.20 & 0.07 & 0.02 \\
\hline Mozambique & 0.78 & 0.12 & 341.96 & 0.00 & 0.00 & 0.02 \\
\hline Namibia & 0.50 & 0.13 & 2685.99 & 0.02 & 0.01 & 0.03 \\
\hline Niger & 0.93 & 0.64 & 169.07 & 0.03 & 0.03 & 0.03 \\
\hline Nigeria & 0.93 & 0.19 & 473.73 & 0.01 & 0.01 & 0.03 \\
\hline Rwanda & 0.89 & 0.08 & 305.45 & 0.02 & 0.02 & 0.03 \\
\hline Sao Tome and Principe & 0.42 & 0.03 & NA & 0.02 & 0.03 & 0.02 \\
\hline Senegal & 0.34 & 0.10 & 532.65 & 0.03 & 0.02 & 0.03 \\
\hline Seychelles & 0.05 & 0.00 & 8349.81 & -0.03 & 0.05 & 0.01 \\
\hline Sierra Leone & 0.84 & 0.11 & 254.10 & 0.02 & 0.02 & 0.02 \\
\hline South Africa & 0.75 & 0.07 & 3704.79 & 0.05 & 0.05 & 0.02 \\
\hline Sudan & 0.83 & 0.23 & 487.18 & 0.12 & 0.13 & 0.03 \\
\hline Swaziland & 0.17 & 0.05 & 1542.22 & 0.03 & 0.02 & 0.03 \\
\hline Togo & 0.88 & 0.16 & 249.80 & 0.00 & 0.00 & 0.03 \\
\hline Tunisia & 0.41 & 0.13 & 2651.99 & 0.17 & 0.03 & 0.02 \\
\hline Uganda & 0.93 & 0.09 & 335.77 & 0.00 & 0.00 & 0.03 \\
\hline United Republic of Tanzania & 0.93 & 0.14 & 408.29 & 0.02 & 0.02 & 0.03 \\
\hline Zambia & 0.86 & 0.07 & 383.02 & 0.03 & 0.02 & 0.03 \\
\hline Zimbabwe & 0.67 & 0.16 & 344.80 & 0.14 & 0.14 & 0.03 \\
\hline
\end{tabular}

Source: The World Bank and FAO dataset

SSR self-sufficiency ratio; $N A$ no data

${ }^{\text {a }}$ The value of the index is in 2007

${ }^{b}$ The value of the index ranges from 1961 to 2007

\section{References}

Acevedo, M. F. (2011). Interdisciplinary progress in food production, food security and environment research. Environmental Conservation, 38(2), 151-171.

Ahotondji, U. V. (2011). Sao Tome and Principe: a model for agricultural success: http://africa.ipsterraviva.net/2011/11/17/sao-tomeand-principe-a-model-for-agricultural-success/

Amalu, U. C. (2002). Food security: sustainable food production in SubSaharan Africa. Outlook on Agriculture, 31(3), 177-185.

Bohle, H. G., Downing, T. E., \& Watts, M. J. (1994). Climate change and social vulnerability: toward a sociology and geography of food insecurity. Global Environmental Change, 4(1), 37-48.

Brown, L. R. (2005). Outgrowing the Earth: The food security challenge in an age of falling water tables and rising temperatures. London: Earthscan.

Clover, J. (2003). Food security in sub-Saharan Africa. African Security Studies, 12(1), 5-15.

de Graaff, J., Kessler, A., \& Nibbering, J. W. (2011). Agriculture and food security in selected countries in Sub-Saharan Africa: diversity in trends and opportunities. Food Security, 3(2), 195-213.

Devereux, S. (2009). Why does famine persist in Africa? Food Security, 1(1), 25-35. 
Dixon, J., Gibbon, D. P., \& Gulliver, A. (2001a). Farming systems and poverty: Improving farmers' livelihoods in a changing world. Rome: FAO and World Bank.

Dixon, J., Gulliver, A., \& Gibbon, D. (2001b). Global farming systems study: Challenges and priorities to 2030. Regional analysis: SubSaharan Africa. Rome: FAO.

Drimie, S., \& Casale, M. (2009). Multiple stressors in Southern Africa: the link between HIV/AIDS, food insecurity, poverty and children's vulnerability now and in the future. Aids Care-Psychological and Socio-Medical Aspects of Aids/Hiv, 21, 28-33.

du Preez, C. C., van Huyssteen, C. W., \& Mnkeni, P. N. S. (2011a). Land use and soil organic matter in South Africa 1: a review on spatial variability and the influence of rangeland stock production. South African Journal of Science, 107(5-6), 27-34.

du Preez, C. C., van Huyssteen, C. W., \& Mnkeni, P. N. S. (2011b). Land use and soil organic matter in South Africa 2: a review on the influence of arable crop production. South African Journal of Science, $107(5-6), 35-42$.

Eriksen, S., O’Brien, K., \& Rosentrater, L. (2008). Climate change in Eastern and Southern Africa: Impacts, vulnerability and adaptation. Project report. Univerisity of Olso. http://www.bvsde.paho.org/ bvsacd/cd68/ClimAfrica.pdf

FAO. (2001). Food balance sheet-A handbook. Rome: FAO.

FAO. (2003). Chapter2. Food security: Concepts and measurement. Trade reforms and food security. Rome: Economic and Social Development Department.

FAO (2011). Global hunger declining, but still unacceptably high: http://www.fao.org/hunger/hunger-home/en/

FAO. (2012). The State of Food Insecurity in the World 2012-Economic growth is necessary but not sufficient to accelerate reduction of hunger and malnutrition. Rome: FAO.

FAOSTAT (2010). http://faostat.fao.org/ Rome: FAO.

Foley, J. A., DeFries, R., Asner, G. P., Barford, C., Bonan, G., Carpenter, S. R., et al. (2005). Global consequences of land use. Science, 309(5734), 570-574.

Gaiser, T., Judex, M., Igue, A. M., Paeth, H., \& Hiepe, C. (2011). Future productivity of fallow systems in Sub-Saharan Africa: is the effect of demographic pressure and fallow reduction more significant than climate change? Agricultural and Forest Meteorology, 151(8), 1120-1130.

Gerbens-Leenes, P. W., \& Nonhebel, S. (2005). Food and land use. The influence of consumption patterns on the use of agricultural resources. Appetite, 45(1), 24-31.

Gerbens-Leenes, P. W., Nonhebel, S., \& Krol, M. S. (2010). Food consumption patterns and economic growth. Increasing affluence and the use of natural resources. Appetite, 55(3), 597-608.

Ghanem, H. (2008). The State of Food Insecruity in the World 2008: High food prices and food security-threats and opportunities. In B. Davis (Ed.), High food prices and food security (pp. 22-31). Rome: FAO

Giorgi, F. (2006). Climate change hot-spots. Geophysical Research Letters, 33(8), L08707.

Godfray, H. C. J., Crute, I. R., Haddad, L., Lawrence, D., Muir, J. F., Nisbett, N., et al. (2010). The future of the global food system. Philosophical Transactions of the Royal Society B-Biological Sciences, 365(1554), 2769-2777.
Gregory, P. J., Ingram, J. S. I., \& Brklacich, M. (2005). Climate change and food security. Philosophical Transactions of the Royal Society B: Biological Sciences, 360(1463), 2139-2148.

Hodrick, R. J., \& Prescott, E. C. (1997). Postwar US business cycles: an empirical investigation. Journal of Money, Credit, and Banking, 29, 1-16.

IFRC. (2006). How to conduct a food security assessment: a step-bystep guide for national societies in africa (second edition). Geneva: International Federation of Red Cross and Red Crescent Societies.

Ivanic, M., \& Martin, W. (2008). Food prices and food security. http:// www.voxeu.org/article/food-prices-and-food-security-don-tblame-liberalisation

Janin, P. (2010). Fighting food insecurity in the Sahel: permanence of questions and evolution of approaches. Cahiers Agricultures, 19(3), 177-184.

Kyle, S. (1999). Agriculture in Sao Tome e Principe: Policy and investment options. New York: Department of Agricultural, Resource, and Managerial Economics, Cornell University, Ithaca.

Lobell, D. B., Burke, M. B., Tebaldi, C., Mastrandrea, M. D., Falcon, W. P., \& Naylor, R. L. (2008). Prioritizing climate change adaptation needs for food security in 2030. Science, 319(5863), 607-610.

Maunder, N., \& Wiggins, S. (2007). Food security in Southern Africa: changing the trend? Review of lessons learnt on recent responses to chronic and transitory hunger and vulnerability. Natural Resources Perspectives, No. 106, ODI

Muller, C., Cramer, W., Hare, W. L., \& Lotze-Campen, H. (2011). Climate change risks for African agriculture. Proceedings of the National Academy of Sciences of the United States of America, 108(11), 4313-4315.

Oxfam (2012). Food crisis in Sahel. http://www.oxfam.org/en/sahel

Pedersen, J., \& Benjaminsen, T. A. (2008). One leg or two? Food security and pastoralism in the northern Sahel. Human Ecology, 36(1), 43-57.

Ramankutty, N., Foley, J. A., Norman, J., \& McSweeney, K. (2002). The global distribution of cultivable lands: current patterns and sensitivity to possible climate change. Global Ecology and Biogeography, 11(5), 377-392.

Rask, K. J., \& Rask, N. (2011). Economic development and food production-consumption balance: a growing global challenge. Food Policy, 36(2), 186-196.

Sadler, M., \& Magnan, N. (2011). Grain import dependency in the MENA region: risk management options. Food Security, 3, S77-S89.

Scanlan, S. J. (2001). Food availability and access in lesser-industrialized societies: a test and interpretation of neo-Malthusian and technoecological theories. Sociological Forum, 16(2), 231-262.

Schlenker, W., \& Lobell, D. B. (2010). Robust negative impacts of climate change on African agriculture. Environmental Research Letters, 5(1), 8.

Schmidhuber, J., \& Tubiello, F. N. (2007). Global food security under climate change. Proceedings of the National Academy of Sciences, 104(50), 19703-19708.

Shiferaw, B., Hellin, J., \& Muricho, G. (2011). Improving market access and agricultural productivity growth in Africa: what role for producer organizations and collective action institutions? Food Security, 1-15.

Smith, P., Gregory, P. J., van Vuuren, D., Obersteiner, M., Havlik, P., Rounsevell, M., et al. (2010). Competition for land. Philosophical Transactions of the Royal Society B-Biological Sciences, 365(1554), 2941-2957. 
Spielman, D. J., Hartwich, F., \& Grebmer, K. (2010). Public-private partnerships and developing-country agriculture: evidence from the International Agricultural Research System. Public Administration and Development, 30(4), 261-276.

Tschirley, D. L., \& Jayne, T. S. (2010). Exploring the logic behind Southern Africa's food crises. World Development, 38(1), 76-87.

Van Zyl, J., \& Coetzee, G. (1990). Food security and structural adjustment: empirical evidence on the food price dilemma in Southern Africa. Development Southern Africa, 7(1), 105-116.

Wang, Y. (2006). Study on China's grain output fluctuations. Beijing: China Agricultural University.

Wang, H. (2009). The theory study of agricultural land use: Based on food security and energy security. Lanzhou: Lanzhou University.

Watkins, K. (2009). Human Development Report 2006-Beyond scarcity: Power, poverty and the global water crisis.

Wirsenius, S., Azar, C., \& Berndes, G. (2010). How much land is needed for global food production under scenarios of dietary changes and livestock productivity increases in 2030? Agricultural Systems, 103(9), 621-638.

World Food Programme. (2011). Libya-Food Security in Libya-An Overview, April 2011. WFP and FAO.

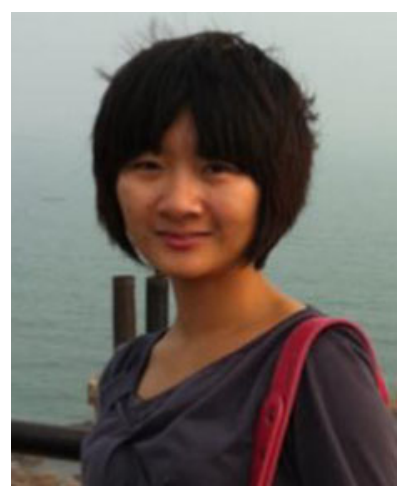

Yibo Luan is a Ph.D. candidate in Global Environmental Change in the College of Global Change and Earth System Science at Beijing Normal University. Her work focuses on the future of Africa's food security. The main topics she interested in are potential yield gaps of crops under climate change in Africa, and the role of Africa in the future of world trade of food.

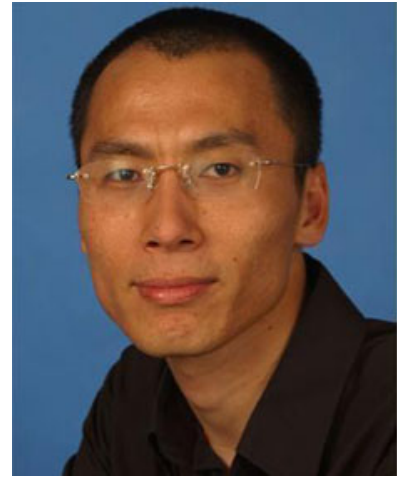

Xuefeng Cui is Associate Professor at the College of Global Change and Earth System Science at Beijing Normal University. Since joining the college in 2010 , he has been focusing on studies of the dynamics and impacts of land use changes, on climate change and food security with remote sensing data and on numerical models at global and regional scales. He has been selected as the Lead Author in the IPCC AR5.

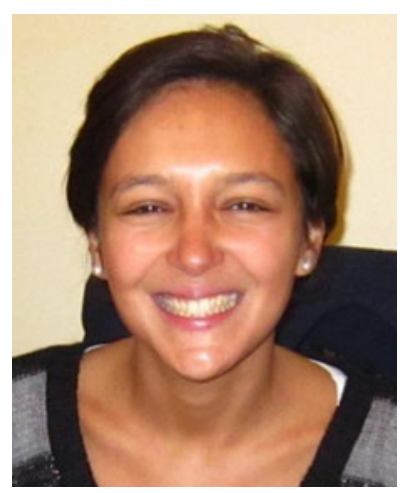

Marion Ferrat earned her Ph.D. in Palaeoclimatology from Imperial College London in 2011, studying the use of fluxes and provenance of mineral dust deposited in central Asia as a proxy for past and present atmospheric circulation patterns. She works as a postdoctoral research assistant in the College of Global Change and Earth System Science at Beijing Normal University, focusing on improving the parameterization of soil properties in the Common Land Model for simulations of permafrost soils in the Arctic. Her research interests include past and present climate change and human-environment interactions. 